\title{
Hot brining of pasta filata cheese: effect of sodium and calcium chloride on composition, yield, and hardness
}

\author{
Balz Bähler ${ }^{1}$ • Alla Kunz ${ }^{1}$ Jörg Hinrichs ${ }^{1}$
}

Received: 10 March 2016 /Revised: 21 May 2016/Accepted: 1 July 2016 /

Published online: 24 August 2016

(C) INRA and Springer-Verlag France 2016

\begin{abstract}
The aim of this study was to investigate how the yield and waterholding capacity of pasta filata cheese during scalding-kneading (approx. $60{ }^{\circ} \mathrm{C}$ ) can be improved by sodium chloride content in the stretching water. This is of sensorial and economic interests. The mechanism of hot bringing was further elucidated by adding calcium chloride in the stretchwater. Pasta filata cheese, comparable with high-moisture mozzarella, was produced in a benchtop batch scalding-kneader, with stretchwater containing 1.0, 2.0 and $2.8 \mathrm{~g} .100 \mathrm{~g}^{-1}$ sodium chloride. Three different kneading times 180, 420, and $600 \mathrm{~s}$ at $60{ }^{\circ} \mathrm{C}$ were tested. After stretching, the stretchwater and the cheese mass were immediately separated and weighed. Protein water-holding capacity increased with increasing sodium chloride content in the stretchwater while the hardness of the cheese decreased. It was shown that during hot brining of pasta filata type cheese, the addition of sodium chloride increased the moisture content of the protein phase and mass yield but decreased the dry matter yield. The addition of calcium chloride during hot brining reduced the moisture-to-protein ratio and increased hardness. In this study, it is demonstrated that hot brining during cookingstretching is a critical process parameter for the composition and texture of pasta filata cheese. Based on these results, composition and hardness of pasta filata cheese can be tailored with salt concentration during stretching. The results also show that the increase of protein voluminosity by sodium is hindered in the presence of calcium ions.
\end{abstract}

Keywords Sodium chloride $\cdot$ Calcium chloride $\cdot$ Texture $\cdot$ Pasta filata cheese $\cdot$ Yield

Balz Bähler

balz.baehler@gmx.net

1 Department of Soft Matter Science and Dairy Technology (150e), Institute of Food Science and Biotechnology, University of Hohenheim, Garbenstr. 21, D-70599 Stuttgart, Germany 


\section{Introduction}

The composition of pasta filata cheese is influenced by process parameters, of which the cooking-stretching step has a large impact (Bähler et al. 2016; Guinee et al. 2000). In this step, the curd is heated, promoting syneresis and fat loss and reducing the final yield of the pasta filata cheese (Bähler et al. 2016). Nevertheless, it has been reported that adding sodium chloride in this step increases the yield (Locci et al. 2012). Sodium chloride is reported to change the conformation of casein proteins (Hussain et al. 2011) and modify the solubility of the different casein fractions (Post et al. 2012). Since cheese is a soft gel of concentrated casein micelles with embedded fat globules and a continuous serum phase, the swelling of this concentrated protein network increases in the presence of sodium chloride (de Kruif et al. 2015; Guo et al. 1997). In particular, the voluminosity (size) of the casein micelles increases (Karlsson et al. 2005).

Salt concentration is an important topic in cheese production and has received increased attention due to efforts towards sodium reduction in human nutrition (Arboatti et al. 2014; IDF 2014). However, salt reduction in pasta filata cheese is not simple because the sodium chloride content influences cheese moisture and hence affects ripening, techno-functional properties, and sensory perception (Ganesan et al. 2014). Pasta filata cheeses contain 0.5 to $4 \mathrm{~g} .100 \mathrm{~g}^{-1}$ sodium chloride, high-moisture mozzarella about $0.7 \mathrm{~g} .100 \mathrm{~g}^{-1}$ and low-moisture mozzarella approximately 1.5 g.100 g ${ }^{-1}$ sodium chloride (Angelis and Gobbetti 2011). Henneberry et al. (2015) showed that the hardness of mozzarella cheese decreases with decreasing salt content. Changes in the chemical composition also influence the flow behavior of the plasticized cheese matrix during melting (Bähler et al. 2015; Henneberry et al. 2015). Salt can be incorporated into pasta filata cheese either by salting the minced curd, hot brining during cooking-stretching, cold brining during cooling, or combinations thereof (Guinee et al. 2000).

During hot brining in the molten state, the curd can easily be mixed for fast and uniform distribution of salt in the cheese matrix, in contrast to diffusion limited cold brining. Rowney et al. (2004) observed an increase in moisture content for hot-brined mozzarella cheese. Paulson et al. (1998) reported that stretching in hot brine reduces the expressible serum (post-manufacture) in comparison to mozzarella cheese produced by dry salting of the minced curd. The increased protein swelling may be induced by higher osmotic stress within the concentrated casein gel compared to the osmotic stress of the solvent (de Kruif et al. 2015).

The calcium content is also important for the structural integrity of the protein network of cheese, composed mainly of casein micelles. During brining, monovalent sodium ions compete and displace divalent calcium ions from binding sites at the carboxyl groups of amino acids within the casein micelles (IDF 2014). Therefore, the calcium content in the serum phase increases with increasing sodium chloride content (Gaucheron et al. 2000; Zhao and Corredig 2015). Other studies (Guinee et al. 2000; Locci et al. 2012) investigating the effect of salt content during cooking-stretching on yield applied a mix of hot brining during cooking-stretching and cold brining during chilling in cold water thereafter so that the effect of the salt content on the cookingstretching step itself is not clearly elucidated. During the cooling step, water absorption or reabsorption is also likely to occur. 
The aim of this study is to understand how hot brining with different sodium chloride and calcium chloride contents in the cooking-stretching step influences composition, yield (protein swelling and stability), and texture of pasta filata cheese. This study excludes with the experimental design any side effects of the cooling on composition and yield during pasta filata cheese. A batch approach was used to guarantee comparable and uniform conditions, since in continuous systems with recycling of stretchwater, the stretchwater composition is likely to change during the experiment impeding proper evaluation.

\section{Material and methods}

\subsection{Cheese curd production}

The cheese curd was produced as described by the authors in a previous paper (Bähler et al. 2016) by direct acidification of pasteurized cow milk (fat-to-protein ratio 0.9) with citric acid. The curd had a final $\mathrm{pH}$ of 5.8. The average chemical composition of the curd was $43.9 \pm 2.5$ g. $100 \mathrm{~g}^{-1}, 20.3 \pm 1.1 \mathrm{~g} .100 \mathrm{~g}^{-1}, 19.8 \pm 1.7 \mathrm{~g} .100 \mathrm{~g}^{-1}$, $45.2 \pm 1.7 \mathrm{~g} .100 \mathrm{~g}^{-1}$, and $2.8 \pm 0.3 \mathrm{~g} . \mathrm{g}^{-1}$ for dry matter, protein content, fat content, fat in dry matter, and moisture-to-protein ratio, respectively.

\subsection{Batch kneading process}

A kitchen machine of the type Thermomix (2 1, TM31, Vorwerk GmbH, Wuppertal, Germany) was chosen as a batch scalding-kneading device (maximum volume $2 \mathrm{~L}$ ) as previously described (Bähler et al. 2016). Sodium chloride (Speisesalz, Saline Bad Reichenhall, Bad Reichenhall, Germany) of 1.0, 2.0, $2.8 \mathrm{~g} .100 \mathrm{~g}^{-1}$ was added to the stretchwater and heated to $80{ }^{\circ} \mathrm{C}$ before addition of the curd. Kneading times of 180 , 420 , and $600 \mathrm{~s}$ were applied. In a further experiment $\mathrm{CaCl}_{2}$ was added to stretchwater with $2.0 \mathrm{~g} .100 \mathrm{~g}^{-1} \mathrm{NaCl}$ and 180-, 420-, and 600-s kneading time. After the addition of curd, the temperature was set to $60{ }^{\circ} \mathrm{C}$. The temperature profile was adjusted and monitored to be similar to the profile given in Bähler et al. (2016).

After kneading, the stretchwater and curd were separated using a sieve and weighed to calculate the mass yield (Eq. 1), the dry matter yield (Eq. 2):

Mass yield $\left(\mathrm{g} \cdot \mathrm{g}^{-1}\right)=\frac{\text { mass pasta filata cheese }(\mathrm{g})}{\text { mass } \operatorname{curd}(\mathrm{g})}$

Dry matter yield $\left(g \cdot g^{-1}\right)=\frac{\text { dry matter cheese } \times \text { mass cheese }(\mathrm{g})}{\text { dry matter curd } \times \text { mass } \operatorname{curd}(\mathrm{g})}$

The mass yield of the scalding-kneading process was defined as the ratio of cheese after kneading compared to initial curd mass. The dry matter yield also considers the changes in dry matter between curd and cheese. The cheese after stretching and sieving 
was cooled in polypropylene boxes during refrigerated storage at $6{ }^{\circ} \mathrm{C}$ until the next day for further analyses.

\subsection{Chemical composition}

The milk and stretchwater composition were analyzed by Fourier transformation infrared spectroscopy (FTIR; Lactoscope, Delta Instruments, Drachten, the Netherlands). The composition of curd and cheese was analyzed as previously described (Bähler et al. 2016). Chloride in the cheese was precipitated after acid hydrolysis with a surplus of silver nitrate, and the excess silver nitrate was determined by titration with ammonium thiocyanate (method C10.6.2, VDLUFA 2003).

\subsection{Texture-profile analysis}

Texture-profile analysis (TPA) was performed with an Instron texture-analyzer (Instron 5944, Instron Deutschland GmbH, Pfungstadt, Germany) with a $50 \mathrm{~N}$ static load cell (Serial No: 100666, Instron Deutschland GmbH, Pfungstadt, Germany) 1 day after production. The cheese was stored at $6{ }^{\circ} \mathrm{C}$ for moisture and protein redistribution. After equilibration for $30 \mathrm{~min}$ at ambient temperature, samples with a diameter of $11 \mathrm{~mm}$ and a height of $15 \mathrm{~mm}$ were prepared from the cheese with a custom-made stainless steel bore and cutting device; TPA was conducted for each sample eight times. A uniaxial compression to $70 \%$ of the original height with a plunger speed of $50 \mathrm{~mm} \cdot \mathrm{min}^{-1}$ was performed. Hardness was defined as the maximal force.

\subsection{Statistical analysis}

The obtained data were analyzed with one-way ANOVA and Tukey's test for pairwise multiple comparison test using SigmaPlot (Systat Software, San Jose, CA, USA). Differences were only identified as significant when $P<0.05$.

\section{Results and discussion}

\subsection{Stretchwater composition}

With increasing sodium chloride content in the stretchwater and with increasing kneading time, the dry matter content of the stretchwater increased (Table 1). The protein content in the stretchwater increased from 0.6 to $0.98 \mathrm{~g} .100 \mathrm{~g}^{-1}$ with increasing sodium chloride content. Fat content in the stretchwater was lower for $1.0 \mathrm{~g} .100 \mathrm{~g}^{-1}$ sodium chloride, but in the same order for 2.0 and $2.8 \mathrm{~g} .100 \mathrm{~g}^{-1} \mathrm{NaCl}$ and was similar to kneading without sodium chloride in pure water, as published previously (Bähler et al. 2016). The fat loss is considerable but in the same range during hot stretching as reported by others (Francolino et al. 2010). A higher fat content in stretchwater is an indication for increased free oil formation (Rowney et al. 2004), the fat migration into stretchwater also reduced mass yield of pasta filata cheese (Locci et al. 2012). Increased protein solubility with increasing sodium chloride content was also observed for directly salted milk (Guinee and Fox 2004) or in the serum phase of brined mozzarella cheese (Guo et al. 1997). 
Table 1 Composition of stretchwater after the production of pasta filata cheese, dependent on kneading time and sodium chloride concentration, analyzed with FTIR. The mean value \pm standard deviation of $n=3$ is shown

\begin{tabular}{llllll}
\hline $\begin{array}{l}\text { NaCl in } \\
\text { stretchwater } \\
\left(\mathrm{g} .100 \mathrm{~g}^{-1}\right)\end{array}$ & $\begin{array}{l}\text { Kneading } \\
\text { time }(\mathrm{s})\end{array}$ & $\begin{array}{l}\text { Dry matter } \\
\left(\mathrm{g} .100 \mathrm{~g}^{-1}\right)\end{array}$ & $\begin{array}{l}\text { Fat } \\
\left(\mathrm{g} .100 \mathrm{~g}^{-1}\right)\end{array}$ & $\begin{array}{l}\text { Protein } \\
\left(\mathrm{g} .100 \mathrm{~g}^{-1}\right)\end{array}$ & $\begin{array}{l}\text { Lactose } \\
\left(\mathrm{g} .100 \mathrm{~g}^{-1}\right)\end{array}$ \\
\hline 1.0 & 180 & $6.6 \pm 0.4^{\mathrm{a}}$ & $3.9 \pm 0.5^{\mathrm{a}}$ & $0.62 \pm 0.05^{\mathrm{a}}$ & $1.13 \pm 0.08^{\mathrm{a}}$ \\
& 420 & $7.1 \pm 0.6^{\mathrm{ab}}$ & $4.3 \pm 0.5^{\mathrm{a}}$ & $0.60 \pm 0.02^{\mathrm{a}}$ & $1.21 \pm 0.07^{\mathrm{a}}$ \\
& 600 & $7.6 \pm 1.3^{\mathrm{ab}}$ & $4.7 \pm 1.4^{\mathrm{ab}}$ & $0.64 \pm 0.05^{\mathrm{a}}$ & $1.42 \pm 0.18^{\mathrm{a}}$ \\
2.0 & 180 & $7.5 \pm 1.5^{\mathrm{ab}}$ & $4.6 \pm 1.0^{\mathrm{ab}}$ & $0.74 \pm 0.08^{\mathrm{ab}}$ & $1.09 \pm 0.17^{\mathrm{a}}$ \\
& 420 & $8.9 \pm 0.7^{\mathrm{ab}}$ & $5.8 \pm 0.6^{\mathrm{ab}}$ & $0.76 \pm 0.03^{\mathrm{ab}}$ & $1.29 \pm 0.06^{\mathrm{a}}$ \\
& 600 & $9.6 \pm 0.5^{\mathrm{bc}}$ & $6.4 \pm 0.5^{\mathrm{b}}$ & $0.75 \pm 0.10^{\mathrm{ab}}$ & $1.37 \pm 0.06^{\mathrm{a}}$ \\
& 180 & $7.8 \pm 0.3^{\mathrm{ab}}$ & $4.8 \pm 0.1^{\mathrm{ab}}$ & $0.98 \pm 0.18^{\mathrm{b}}$ & $1.21 \pm 0.20^{\mathrm{a}}$ \\
& 420 & $9.2 \pm 0.2^{\mathrm{bc}}$ & $5.9 \pm 0.1^{\mathrm{ab}}$ & $0.89 \pm 0.12^{\mathrm{ab}}$ & $1.35 \pm 0.07^{\mathrm{a}}$ \\
& 600 & $10.4 \pm 0.5^{\mathrm{c}}$ & $7.1 \pm 0.6^{\mathrm{b}}$ & $0.92 \pm 0.12^{\mathrm{ab}}$ & $1.49 \pm 0.10^{\mathrm{a}}$ \\
\hline
\end{tabular}

Measured values with the same superscript in one column are not statistically different $(P \geq 0.05)$

\subsection{Mozzarella composition with sodium chloride}

The mass yield after kneading, i.e. cheese to initial curd ratio, was in the range of 0.85 to $0.92 \mathrm{~g} \cdot \mathrm{g}^{-1}$ (Table 2). The dry matter content in this study varied between $43.6 \mathrm{~g} .100 \mathrm{~g}^{-1}$ for $1 \% \mathrm{NaCl}$ and $180 \mathrm{~s}$ kneading time to $34.5 \mathrm{~g} .100 \mathrm{~g}^{-1}$ for $2.8 \%$ $\mathrm{NaCl}$ and $600 \mathrm{~s}$ kneading time. The dry matter yield was in the range from 0.74 to $0.86 \mathrm{~g} . \mathrm{g}^{-1}$. This means that some material dissolved from the curd during kneading in the stretchwater, reducing the dry matter yield. In general, the dry matter decreased with increasing sodium chloride content irrespective of kneading time.

For the formulation with $1.0 \mathrm{~g} .100 \mathrm{~g}^{-1}$ sodium chloride, the moisture-to-protein ratio decreased from 2.5 to $2.2{\mathrm{~g} . \mathrm{g}^{-1}}^{-1}$ (Table 2) with increasing kneading time. Nevertheless, this is smaller than the initial moisture-to-protein ratio of $2.8 \mathrm{~g} . \mathrm{g}^{-1}$ in the curd. For 2.0 and $2.8 \mathrm{~g} .100 \mathrm{~g}^{-1}$ sodium chloride in the stretchwater, the moisture-to-protein ratio and mass yield remained unchanged during the scalding-kneading step (Table 2). Kneading with $2.8 \% \mathrm{NaCl}$ in the solution resulted in higher cheese moisture-to-protein ratio compared to the initial curd.

However, during the first $180 \mathrm{~s}$ kneading time, the desired temperature of $60^{\circ} \mathrm{C}$ was not achieved. It had an average of $57.4^{\circ} \mathrm{C}$ because the curd has to warm up first and this step is restrictive (Bähler et al. 2016). After $420 \mathrm{~s}$, the desired temperature of $60{ }^{\circ} \mathrm{C}$ was reached. This indicates that a temperature equilibrium was achieved. The protein content remained constant, whereas the dry matter content decreased (Table 2) mainly due to fat losses into the stretchwater (Table 1). The overall weight of cheese after stretching, compared to the initial curd, expressed as mass yield remained constant because of the increased moisture content. Therefore, the sodium chloride absorption of the protein phase increased with increasing kneading time due to the time required for equilibration and inward diffusion into the shredded curd particles. The apparent diffusion coefficient in the pasta filata cheese matrix increases with rising temperature and with higher moisture content. Under equilibrium conditions, the cheese moisture should have the same sodium chloride content 


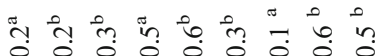

H H H H H H H H H

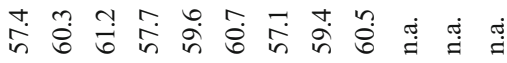

¿

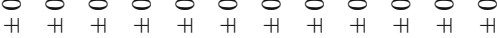

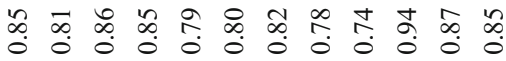

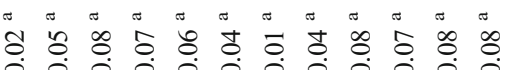

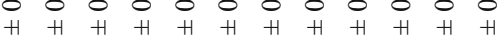

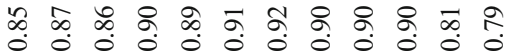

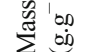

$\frac{n}{2}$

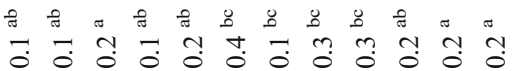

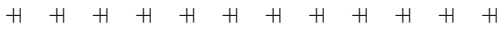

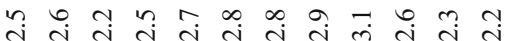

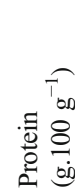

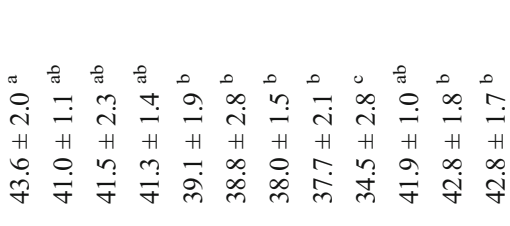

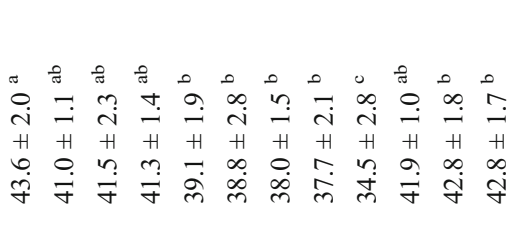

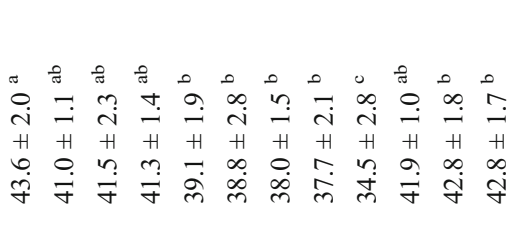

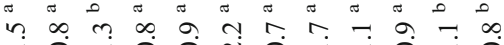

H H H H H H H H H H H

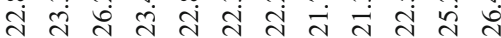


as the stretchwater. Since this is a batch process, the sodium chloride content in the stretchwater decreased with increasing kneading time. At the end of the experiment, the sodium chloride content of the cheese kneaded for $420 \mathrm{~s}$ was $0.6,0.9$, and $1.1 \mathrm{~g} .100 \mathrm{~g}^{-1}$ for $1.0,2.0$, and $2.8 \mathrm{~g} .100 \mathrm{~g}^{-1} \mathrm{NaCl}$ in the stretchwater, respectively.

For scalding-kneading without any salt added, the mass yield decreased with increasing kneading time from $0.80 \mathrm{~g} . \mathrm{g}^{-1}$ after $180 \mathrm{~s}$ to $0.71 \mathrm{~g} . \mathrm{g}^{-1}$ after $600 \mathrm{~s}$ due to reduced moisture retention measured as moisture-to-protein ratio (Bähler et al. 2016). The observed increase in moisture-to-protein content with sodium chloride indicates an increasing water-holding capacity of the cheese with salt, which counteracted the reduced voluminosity of the casein micelles with increasing temperature, which was observed for casein micelle solutions (Nöbel et al. 2012). The mass yield remained constant with increasing kneading time, except for the case of $1 \mathrm{~g} .100 \mathrm{~g}^{-1}$ sodium chloride. An influence of protein on yield also explains the lower dry matter yields compared to mass yields.

Increased moisture-to-protein ratio with increased sodium chloride levels has already been described by others in the context of a reduced serum phase of pasta filata cheese (Guo et al. 1997; Paulson et al. 1998; Rowney et al. 2004). Sodium chloride up to approximately $1 \mathrm{~g} .100 \mathrm{~g}^{-1}$ is reported to induce swelling of casein gels (de Kruif et al. 2015). The hydrophobic interactions between caseins and the mineral equilibrium are altered (Gaucheron et al. 2000), and the ionic strength of the serum phase increases, reducing the electrostatic repulsion of colloidal casein micelles (Zhao and Corredig 2015). In contradiction to the study of de Kruif et al. (2015), we could not observe a decrease in the water-holding capacity of the casein gel (moisture-to-protein ratio) with decreasing sodium chloride content. Nevertheless, a temperature effect on moisture retention has previously been reported by Ganesan et al. (2014) who decreased the temperature during stretching of reduced-salt mozzarella production to achieve the same moisture content.

These results suggest that the water-holding capacity of protein in pasta filata cheese can be increased with sodium chloride at elevated temperatures. Protein water-holding capacity and the final moisture content of pasta filata cheese can thus be tailored by the composition of the stretchwater. The effects on "free water" during kneading have to be considered during cooking-stretching as the change in composition is assumed to influence the rheological and functional properties.

\subsection{Texture-profile analysis}

Functional characteristics such as texture are modified as the composition of cheese changes. An instrumental measure for texture is texture-profile analysis. The hardness shown in Fig. 1 is the peak force at maximum compression during the first compression cycle, as the samples did not fracture during compression. From Fig. 1, the hardness of the pasta filata type cheese increased while the dry matter content decreased with increasing kneading time. The dry matter content and hardness were lower at higher sodium chloride content in the stretchwater. Hence, for the same dry matter content, the hardness increased with decreasing sodium chloride content, indicating that the increased moisture-to-protein content resulted in a decrease in the gel strength of the cheese matrix. There is also a timedependent behavior of the cheese since with increasing kneading time from 180 to 


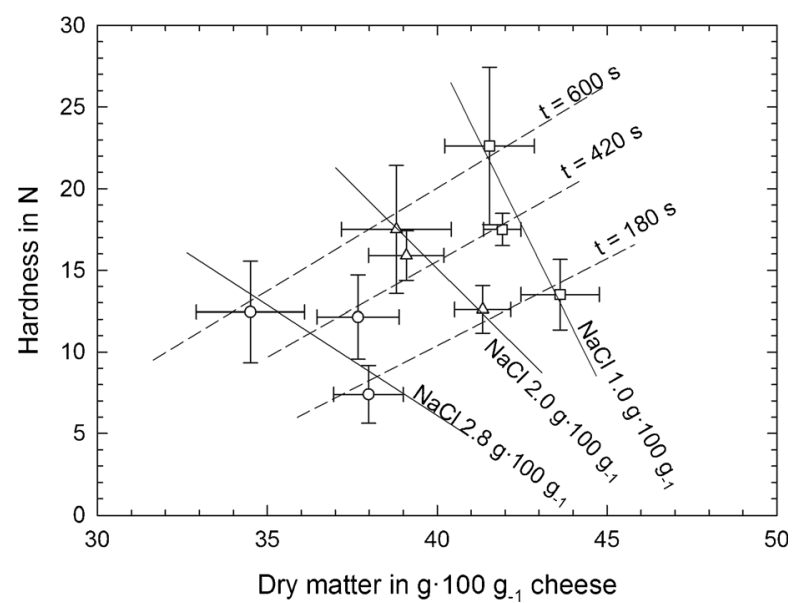

Fig. 1 Trend between dry matter and hardness of cheese obtained after different scalding-kneading conditions $\left(\mathrm{NaCl}\right.$ content in the initial stretchwater: square $1.0 \mathrm{~g} .100 \mathrm{~g}^{-1}$, triangle $2.0 \mathrm{~g} .100 \mathrm{~g}^{-1}$, empty circle $2.8 \mathrm{~g} .100 \mathrm{~g}^{-1}$ ), error bars indicate the standard error from three independent replications, lines are to guide the eyes

$600 \mathrm{~s}$, the moisture content and hardness increased, the sodium chloride content in the stretchwater decreased, and in the cheese increased altering the osmotic stress and pressure.

de Kruif et al. (2015) postulated that the osmotic pressure is related to the gel strength. The increasing sodium chloride content increased casein micelle waterholding capacity so that the dry matter content is reduced. Casein micelles gels with a higher voluminosity are softer compared to casein gels with a lower water content and reduced diameter. This is in agreement with the observed decrease in hardness with increasing sodium chloride content. These results confirm that hot brining at low salt content has different effects on cheese texture than cold brining (higher sodium chloride concentrations, 15-20\%) where the hardness increases and the moisture content decreases with increasing sodium chloride content of the brine (Kindstedt 2001; Luo et al. 2013).

\subsection{Effect of calcium chloride}

For cold brining, the addition of divalent cationic calcium ions reduces the voluminosity of caseins. This reduces the protein release and increases the hardness of the cheese. The hypothesis that this can also be added to tailor the moisture content and hardness during hot brining was tested in a subsequent experiment. The sodium chloride concentration of $2 \mathrm{~g} .100 \mathrm{~g}^{-1}$ stretchwater was chosen as a model.

It was observed that with the addition of $0.02 \mathrm{~g} .100 \mathrm{~g}^{-1}$ calcium chloride into the stretchwater, the mass yield decreased to $0.8 \mathrm{~g} . \mathrm{g}^{-1}$ compared to $0.9 \mathrm{~g} . \mathrm{g}^{-1}$ without calcium chloride (Table 2). In addition, the moisture-to-protein content decreased because the protein content increased with kneading time. Stretching with calcium chloride and $2 \%$ sodium chloride yielded a product with similar composition as $1 \%$ sodium chloride and no calcium chloride (Table 2). The increasing protein content 


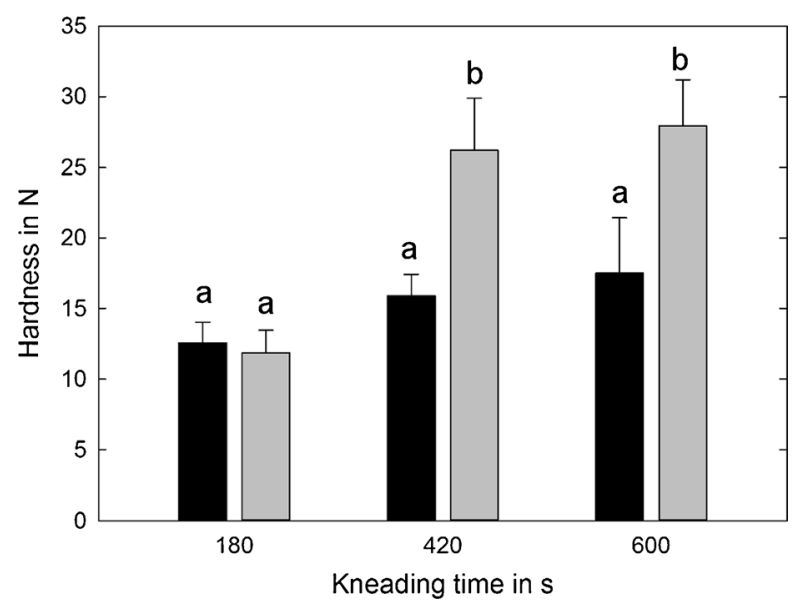

Fig. 2 Hardness of cheese after different kneading times for $2 \mathrm{~g} .100 \mathrm{~g}^{-1}$ sodium chloride in the stretchwater, without calcium chloride (black bars) and with $0.02 \mathrm{~g} .100 \mathrm{~g}^{-1}$ calcium chloride additionally (gray bars). Bars with the same letter are not statistically different $(P \geq 0.05)$, error bars indicate standard deviation

with calcium chloride indicates a decreasing protein water-holding capacity with temperature as observed by Bähler et al. (2016). Luo et al. (2013) found that the moisture content was reduced in mozzarella cheese when calcium chloride was added to cold brine. This observation is consistent with the hypothesis that the increased protein water-holding capacity after kneading in sodium chloride solution is partly due to the loss of calcium ions into the stretchwater. The loss of calcium has also been proven to be related to extensive surface softening of mozzarella cheese (Kindstedt et al. 1996; Luo et al. 2013).

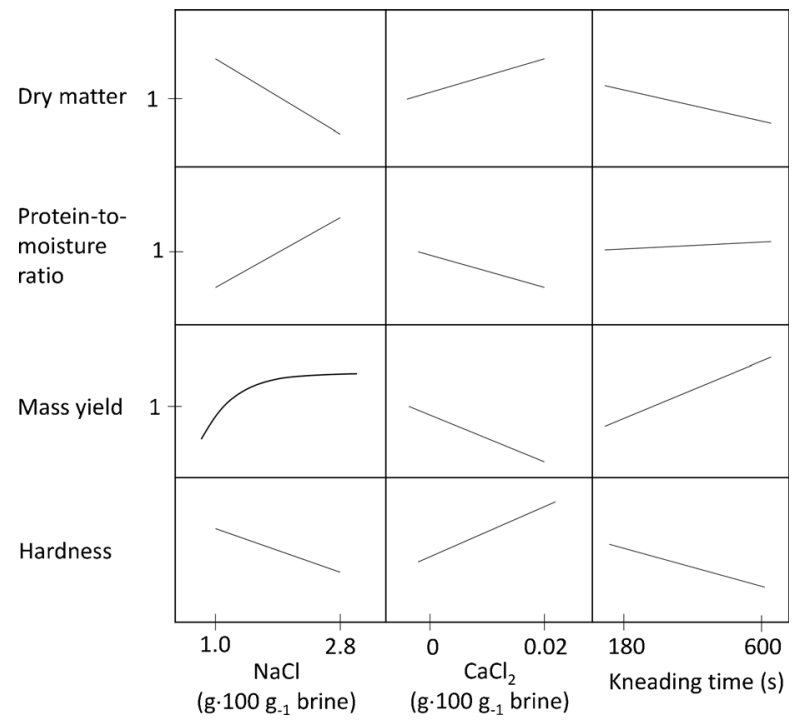

Fig. 3 Schematic summary and qualitative relationship of hot brining parameters, sodium chloride content in stretchwater, calcium chloride content in stretchwater, and kneading time. 1 is the value for curd, and the line is the value for cheese as ratio of cheese to curd 
The protein de-swelling in the presence of calcium ions may be due to increased ionic strength of the serum phase and increasing interactions of casein with colloidal calcium phosphate clusters within the casein micelles ( $\mathrm{pH}$ 5.8). Since calcium solubility is limited and decreases with increasing temperature, the formation of colloidal calcium is favored. The results are in agreement with the assumption of calcium chloride being a relatively bad solvent and inducing de-swelling of casein gels (de Kruif et al. 2015). Addition of calcium, a chaotrophic ion within the Hofmeister series of salts, should weaken the hydrophobic interactions of proteins, but this was not observed in this study. We suppose that the calcium concentration in the cheese serum is already close to saturation restricting additional solubilization.

The cheese hardness also increased with calcium chloride addition and kneading time (Fig. 2). The hardness was not correlated to the dry matter content like the data in Fig. 1 but rather with the protein content and the moisture-toprotein ratio (Table 2). Therefore, an increase in hardness was observed after a kneading time of $420 \mathrm{~s}$ (Fig. 2). This correlates with reduced voluminosity, increased protein content, and a harder, denser gel structure. It was also evident from this study that decreased protein voluminosity and increased hardness due to calcium chloride addition are not exclusive to cold brining and also relevant for hot brining.

\section{Conclusions}

The pasta filata cheese investigated in this study best represents the production process of high-moisture mozzarella cheese in terms of moisture and salt content. The effect of hot brining during scalding-kneading on mass yield and composition, as summarized in Fig. 3, was determined with the bench top system utilized. Based on Fig. 1, we propose that there is a dry matter and hardness response for each salt concentration. The dry matter content decreased and the moisture content increased with increasing sodium chloride content. Therefore, swelling of the casein gel for the investigated concentration of sodium chloride is postulated. Interestingly, even at the same dry matter content, the hardness decreased with increasing sodium chloride content. With calcium chloride addition, shrinkage of cheese mass was observed due to the displacement of water.

For pasta filata cheese producers, this means that a reduction in salt content requires an adjustment of the process conditions due to increased hardness and reduced moisture content (Fig. 3). Hot brining in the range of 1.0 to $2.8 \mathrm{~g} .100 \mathrm{~g}^{-1}$ $\mathrm{NaCl}$ was found to increase the mass yield during the scalding-kneading process of pasta filata cheese production, and this was due to an increased moisture-toprotein content in contrast to classical cold brining. Therefore, sodium chloride addition during scalding-kneading increases protein voluminosity and counteracts moisture loss during heating. Heat increases hydrophobic protein interactions whereas hydrophobic interactions decrease with increasing sodium chloride concentration. In contrast, when stretchingwater is a mixture of sodium and calcium chloride, hydrophobic interactions are again predominated and the swelling effect of sodium chloride is hindered. The increase in protein water-holding capacity at the same temperature was also found to decrease the hardness of the cheese gel. 
These findings suggest different possibilities to adapt the process temperature to tailor the texture of reduced-salt pasta filata cheese during scalding-stretching.

Acknowledgments We thank Luc Mertz and Nabil Chaib for the assistance with the milk processing, Felix Gärtner and Ramona Bast for the assistance during kneading experiments, and Sonja Haas and Birgit Greif for the support with the analysis. This project has received funding from the European Union's Seventh Framework Programme for research, technological development, and demonstration under grant agreement no 613968.

Compliance with ethical standards This article does not contain any studies with human or animal subjects performed by any of the authors.

Conflict of interest All authors declare that they have no conflict of interest.

\section{References}

Angelis MD, Gobbetti M (2011) CHEESE | pasta-filata cheeses: traditional pasta-filata cheese. In: Fuquay JW (ed) Encyclopedia of dairy sciences (second edition), 2nd edn. Academic Press, San Diego, pp. 745-752

Arboatti AS, Olivares ML, Sabbag NG, Costa SC, Zorrilla SE, Sihufe GA (2014) The influence of sodium chloride reduction on physicochemical, biochemical, rheological and sensory characteristics of mozzarella cheese. Dairy Sci Technol 94:373-386

Bähler B, Back R, Hinrichs J (2015) Evaluation of oscillatory and shear strain behaviour for thermorheological plasticisation of non-ripened cheese curd: effect of water, protein, and fat. Int Dairy $\mathrm{J} 46$ : 63-70

Bähler B, Ruf T, Samudrala R, Schenkel P, Hinrichs J (2016) Systematic approach to study temperature and time effects on yield of pasta filata cheese. Int J Dairy Technol 69:184-190. doi:10.1111/14710307.12248

de Kruif CG, Anema SG, Zhu C, Havea P, Coker C (2015) Water holding capacity and swelling of casein hydrogels. Food Hydrocoll 44:372-379

Francolino S, Locci F, Ghiglietti R, Iezzi R, Mucchetti G (2010) Use of milk protein concentrate to standardize milk composition in Italian citric mozzarella cheese making. LWT-Food Sci Technol 43:310-314

Ganesan B, Brown K, Irish DA, Brothersen C, McMahon DJ (2014) Manufacture and sensory analysis of reduced- and low-sodium cheddar and mozzarella cheeses. J Dairy Sci 97:1970-1982

Gaucheron F, Le Graet Y, Briard V (2000) Effect of $\mathrm{NaCl}$ addition on the mineral equilibrium of concentrated and acidified casein micelles. Milchwissenschaft 55:82-86

Guinee TP, Fox PF (2004) Salt in cheese: physical, chemical and biological aspects. In: Fox PF, McSweeney PLH, Cogan TM, Guinee TP (eds) Cheese chemistry, physics and microbiology, Cheese: Chemistry, Physics and Microbiology, vol 1. Academic Press, San Diego, pp. 207-259

Guinee TP, Mulholland EO, Mullins C, Corcoran MO (2000) Effect of salting method on the composition, yield and functionality of low moisture mozzarella cheese. Milchwissenschaft 55:135-138

Guo MR, Gilmore JA, Kindstedt PS (1997) Effect of sodium chloride on the serum phase of mozzarella cheese. J Dairy Sci 80:3092-3098

Henneberry S, Wilkinson MG, Kilcawley KN, Kelly PM, Guinee TP (2015) Interactive effects of salt and fat reduction on composition, rheology and functional properties of mozzarella-style cheese. Dairy Sci Technol 95:613-638

Hussain R, Gaiani C, Aberkane L, Ghanbaja J, Scher J (2011) Multiscale characterization of casein micelles under $\mathrm{NaCl}$ range conditions. Food Biophys 6:503-511

IDF (2014) The importance of salt in the manufacture and ripening of cheese - special issue of the international dairy federation SI-1401. International Dairy Federation, Brussels

Karlsson AO, Ipsen R, Schrader K, Ardö Y (2005) Relationship between physical properties of casein micelles and rheology of skim milk concentrate. J Dairy Sci 88:3784-3797

Kindstedt PS (2001) Moisture variations in brine-salted pasta filata cheese. J AOAC Int 84:605-612

Kindstedt PS, Larose KL, Gilmore JA, Davis L (1996) Distribution of salt and moisture in mozzarella cheese with soft surface defect. J Dairy Sci 79:2278-2283 
Locci F, Ghiglietti R, Francolino S, Iezzi R, Mucchetti G (2012) Effect of stretching with brine on the composition and yield of high moisture mozzarella cheese. Milchwissenschaft 67:81-85

Luo J, Pan T, Guo HY, Ren FZ (2013) Effect of calcium in brine on salt diffusion and water distribution of mozzarella cheese during brining. J Dairy Sci 96:824-831

Nöbel S, Weidendorfer K, Hinrichs J (2012) Apparent voluminosity of casein micelles determined by rheometry. J Colloid Interf Sci 386:174-180

Paulson BM, McMahon DJ, Oberg CJ (1998) Influence of sodium chloride on appearance, functionality, and protein arrangements in nonfat mozzarelia cheese. J Dairy Sci 81:2053-2064

Post AE, Arnold B, Weiss J, Hinrichs J (2012) Effect of temperature and pH on the solubility of caseins: environmental influences on the dissociation $\alpha_{\mathrm{s}}$ and $\beta$-casein. J Dairy Sci 95:1603-1616

Rowney MK, Roupas P, Hickey MW, Everett DW (2004) Salt-induced structural changes in 1-day old mozzarella cheese and the impact upon free oil formation. Int Dairy J 14:809-816

VDLUFA (2003) Handbuch der Landwirtschaftlichen Versuchs- und Untersuchungs-methodik, Methodenbuch Band VI: Milch und Milchprodukte. VDLUFA-Verlag, Darmstadt

Zhao Z, Corredig M (2015) Changes in the physico-chemical properties of casein micelles in the presence of sodium chloride in untreated and concentrated milk protein. Dairy Sci Technol 95:87-99 